\title{
The Government Contract Defense in Strict Liability Suits for Defective Design
}

The United States government usually does not produce its own goods; instead, it contracts to have goods produced by the private sector. The government chooses different roles in its contractual relations, ranging from purchasing only an end product and leaving the production process in the hands of an independent contractor, ${ }^{3}$ to controlling the raw materials and production process as well, leaving the contractor to supervise the operation of the plant. ${ }^{2}$

This comment focuses on the problems that arise when a strict products liability suit alleges a defect in a product designed by the government and manufactured by a private contractor. In the case of a manufacturing defect, most courts place liability on the contractor. ${ }^{3}$ In the case of a design defect, the responsibility is logically the government's. Yet sovereign immunity often protects the government from liability-both from the plaintiff in a direct tort action for defective design and from the contractor in an indemnity suit. This immunity forces the courts to allocate costs between the contractor and the injured plaintiff. Seeking to avoid liability, the contractor asserts a "government contract" defense. This comment argues that this defense should fail in all cases except where the contractor has been coerced into making the contract. Strict contractor liability serves a vital function, for contractors are in the best position to induce the government to absorb its share of liability costs through adjustments in its contractual relationships.

'See Ingrado, Types of Government Contracts, 18 A.F.L. Rev. 63, 64-68 (1976).

2 See, e.g., Powell v. United States Cartridge Co., 339 U.S. 497 (1950) (governmentowned munitions plant operated by private contractors).

3 One commentator has said that "the manufacturing flaw area represents a happy coincidence of the substantively desirable and the institutionally feasible." Henderson, Judicial Review of Manufacturers' Conscious Design Choices: The Limits of Adjudication, 73 Colum. L. Rev. 1531, 1546 (1973). 


\section{Definition of Terms}

\section{A. Design Defects}

There are two basic types of products liability actions: those for manufacturing defects and those for defects in design. ${ }^{4}$ Products with manufacturing defects do not conform to the intended design or to the majority of products made according to the design; the design thus serves as a standard by which a court can measure the deviation caused by the manufacturing flaw. Where there is a design defect, on the other hand, the product conforms to the intended design, but the design itself is dangerous. There are two kinds of design defects. An inadvertent design error, which courts may treat as a manufacturing flaw, is unwitting and inhibits the intended use of the product. A conscious design choice, in contrast, is chosen by the manufacturer for its utility despite its inherent risk of harm. Because there is no internal standard by which to judge defectiveness in cases of conscious design choice, courts must devise their own tests of reasonableness, weighing the utility of the product against the risk of harm. For purposes of the government contract defense, the analysis should proceed similarly in both the inadvertent design defect and the conscious design choice cases. ${ }^{\circ}$

In some cases of conscious design choice, courts impose a duty to warn if the warning can make an otherwise unreasonably dangerous product acceptable. ${ }^{6}$ The government contractor should be

Id. at 1542-44. The distinctions drawn in text are essentially those drawn by Henderson.

${ }^{3}$ This comment does not discuss the difficulties inherent in the concept of a design defect or the competence of courts to resolve them. See generally R. EPSTEIN, MoDERN Products Liability Law 68-93 (1980); Henderson, supra note 3, at 1565-77; Henderson, Renewed Judicial Controversy Over Defective Product Design: Toward the Preservation of an Emerging Consensus, 63 MinN. L. REv. 773 (1979). A more favorable view of the design defect concept and the courts' performance is found in Twerski, Weinstein, Donaher \& Piehler, The Use and Abuse of Warnings in Products Liability-Design Defect Litigation Comes of Age, 61 CoRnell L. REv. 495 (1976) [hereinafter cited as Twerski].

Nor does the comment discuss judicial reluctance to find government design defects, see, e.g., Hunt v. Blasius, 74 Ill. 2d 203, 384 N.E.2d 368 (1978); Sanner v. Ford Motor Co., 144 N.J. Super. 1, 364 A.2d 43 (Super. Ct. Law Div. 1976), aff'd, 154 N.J. Super. 407, 381 A.2d 805 (Super. Ct. App. Div. 1977), for the analysis should not vary with the identity of the designer.

- See, e.g., McCormack v. Hankscraft Co., 278 Minn. 322, 333, 154 N.W.2d 488, 496-97 (1967) (manufacturer liable for failure to warn of dangers of hot water vaporizer jar). Where even a proper warning cannot render the design of the product safe enough to market, courts rely directly on design defect analysis. Id. at 333-34, 154 N.W.2d at 497. See also Twerski, supra note 5, at 500-05. 
liable for the government designer's failure to warn:" a product that is unreasonably dangerous because there is no warning should be treated like a product that is unreasonably dangerous because of an inadvertent design defect. If following government specifications would be insufficient to relieve the contractor of liability in the latter instance, the government contract defense should be denied in the former as well. ${ }^{8}$

\section{B. The Government Contract Defense}

The essence of the government contract defense is that the contractor, by relying on government design specifications, should be absolved of liability for defective design. Unless design defects are "glaring and obvious," contractors escape liability in negligence actions by showing they complied with government specifications. ${ }^{9}$ Courts do not agree, however, on the availability of the government contract defense in strict products liability. Some jurisdictions extend such liability to parties like the contractor who, although they did not create the defect, were in the chain of distribution and exerted control over the defective product. ${ }^{30}$ Other jurisdictions reject this extension of liability and allow the government contract defense even in strict products liability suits. ${ }^{11}$

I Moreover, where the contractor is the cheapest cost avoider, he should be liable for his own failure to warn. See Calabresi \& Hirschoff, Toward a Test for Strict Liability in Torts, 81 YALE L.J. 1055, 1062 (1972).

B When a government employee is injured, the government fills two roles: employer and designer. For the view that the duty to warn should not attach to the manufacturer of a product when there is a "responsible intermediary" such as the government employer between the manufacturer and the ultimate user, see R. EPSTEIN, supra note 5, at 93-110.

${ }^{9}$ Littlehale v. E.I. du Pont de Nemours \& Co., 268 F. Supp. 791, 802 n.16 (S.D.N.Y. 1966) (maritime law), aff'd, 380 F.2d 274 (2d Cir. 1967). See also Ryan v. Feeney \& Sheehan Bldg. Co., 239 N.Y. 43, 145 N.E. 321 (1924); text and notes at notes 31-34 infra.

${ }_{10}$ For instance, in Challoner v. Day \& Zimmermann, Inc., 512 F.2d 77 (5th Cir.) (Texas law), vacated on choice of law grounds, 423 U.S. 3 (1975), the plaintiff sued a government contractor who had manufactured a defective howitzer round. The round was produced according to government design specifications. The Fifth Circuit, applying Texas strict liability law, upheld liability for the design defect despite the defendant's argument that the design was exclusively in the control of the government. The court distinguished negligence and strict liability: "A strict liability case, unlike a negligence case, does not require that the defendant's act or omission be the cause of the defect. It is only necessary that the product be defective when it leaves the defendant's control." Id. at 83. See also Foster v. Day \& Zimmermann, Inc., 502 F.2d 867 (8th Cir. 1974) (Iowa law). Most jurisdictions apply this form of analysis to hold retailers liable for defects created by the manufacturer. See note 37 infra.

${ }^{11}$ For instance, in Hunt v. Blasius, 55 Ill. App. 3d 14, 370 N.E.2d 617 (1977), aff'd, 74 


\section{The Legal Framework}

There are three actors in the government design defect situation-the injured plaintiff, the contractor, and the government. Each seeks to avoid the burden of defective design specifications. Because sovereign immunity usually protects the government, the availability of the government contract defense is crucial to deciding whether the plaintiff or the contractor bears the burden of the defect. This part explores how the legal framework distributes that burden, with an eye to evaluating the government contract defense in the strict liability context. To do so, it analyzes the rules governing suits by plaintiffs against the government, by plaintiffs against contractors, and by contractors against the government; it then examines the additional defenses that contractors may assert against plaintiffs.

\section{A. Plaintiff v. United States}

1. Negligence. In 1946 Congress enacted a limited waiver of sovereign immunity in the Federal Tort Claims Act ("FTCA"). ${ }^{12}$ The Act permits suit against the government but exempts a number of government actions from its ambit. For example, the government is not liable for many discretionary acts of its employees. ${ }^{13}$

The Supreme Court applied the discretionary function exception to government specifications in Dalehite $v$. United States, ${ }^{14}$ a

Ill. $2 \mathrm{~d} 203,384$ N.E.2d 368 (1978), the plaintiffs were injured when their vehicle collided with a steel sign pole embedded in concrete. They claimed that the designs of both the pole and the highway were defective. The trial and intermediate courts agreed that the complaint stated a cause of action for design defect, but ruled that adherence to state specifications relieved the pole manufacturer of liability. Id. at 20,370 N.E.2d at 621-22. Eor an approving appraisal of the appellate court opinion, see Note, Hunt v. Blasius: $A$ Gap in the Application of the Illinois Strict Products Liability Theory, 11 Lov. CHI. L.J. 147 (1979). The Illinois Supreme Court found no defect. 74 Ill. 2d 203, 212, 384 N.E.2d 368, 372 (1978). For another successful government contract defense case, see Sanner v. Ford Motor Co., 144 N.J. Super. 1, 364 A.2d 43 (Super. Ct. Law Div. 1976), aff'd, 154 N.J. Super. 407, 381 A.2d 805 (Super. Ct. App. Div. 1977).

${ }^{12}$ Act of Aug. 6, 1946, ch. 753, 60 Stat. 842 (codified primarily at 28 U.S.C. $\$ \S 2671$ 2680 (1976)).

13 The discretionary function exception provides that no liability shall attach to:

Any claim based upon an act or omission of an employee of the Government, exercising due care, in the execution of a statute or regulation, whether or not such statute or regulation be valid, or based upon the exercise or performance or the failure to exercise or perform a discretionary function or duty on the part of a federal agency or an employee of the Government, whether or not the discretion involved be abused.

Id. $\$ 2680(\mathrm{a})$.

14346 U.S. 15 (1953). 
negligence action for deaths caused by an explosion of ammonium nitrate fertilizer produced and shipped under government control. The Court held that the discretionary function exception "includes determinations made by executives or administrators in establishing plans, specifications or schedules of operations."15 Because the decisions were made at the planning, rather than the operational level, the Court denied recovery under the FTCA. ${ }^{16}$

In elaborating the Dalehite definition of the discretionary function exception, lower courts have developed a test, inconsistently applied, based on whether the design reflects a government "policy" decision. ${ }^{17}$ Under this test, the government escapes liability if its designs embody policy choices; if they do not, the government may be sued. ${ }^{18}$ Until the Supreme Court develops a more rigorous definition of this exception, the availability of a negligence suit against the government for its design defects is problematic. ${ }^{19}$

2. Strict Liability. The Supreme Court's decision in Laird $v$. $N e l m s^{20}$ precludes a suit against the government based on strict liability. Nelms sued for damage caused by the sonic boom of a military plane, basing his case on a theory of strict liability for ultrahazardous activities. The Court concluded that the FTCA per-

15 Id. at 35-36 (footnote omitted).

${ }^{16} I d$.

${ }^{17}$ See Zillman, The Changing Meanings of Discretion: Evolution in the Federal Tort Claims Act, 76 Mrr. L. Rev. 1 (1977); Comment, Federal Tort Claims: A Critique of the Planning Level-Operational Level Test, 11 U.S.F.L. REv. 170, 179 n.60 (1976), and cases cited therein.

18 See, e.g., Moyer v. Martin Marietta Corp., 481 F.2d 585 (5th Cir. 1973) (selection of B-57 aircraft by Secretary of the Air Force was discretionary function; acceptance of aircraft system, such as an ejection seat and its mechanism, was not); Stanley v. United States, 347 F. Supp. 1088 (D. Me. 1972) (federal design of radio tower excluding guard rail not discretionary function unless related to policy considerations underlying decision to engage in particular activity), vacated on other grounds, 476 F.2d 606 (1st Cir. 1973). Cf. Daniel v. United States, 426 F.2d 281 (5th Cir. 1970) (United States cannot be sued for negligent design of concrete traffic separator because approval of plans and specifications for interstate highway in accordance with criteria of traffic needs, safety, durability, and economy of maintenance is a discretionary function).

19 Even where a plaintiff can sue the United States in negligence, the alternative of suing the contractor still should be available. The equities may shift somewhat in favor of the contractor, because the plaintiff with a FTCA action against the government can achieve directly what the contractor's suit accomplishes indirectly: it forces the government to absorb the true costs of its procurement programs. See part III infra. But the FTCA is not, by its terms, restricted to plaintiffs with no other cause of action. See Zillman, supra note 17, at 36-37. Nor is the common law cause of action against the contractor superseded by the creation of a statutory cause of action against the United States. Brady v. Roosevelt Steamship Co., 317 U.S. 575, 579 (1943).

20406 U.S. 797 (1972). 
mits recovery only for a "negligent or wrongful act or omission"21 and that absolute liability therefore was precluded. Although the decision has been the subject of much criticism, ${ }^{22}$ the Court has not repudiated it.

3. Additional Statutory Relief. Other statutes provide limited relief against the United States in special circumstances. If the plaintiff is a government employee or in the military service, he falls within the federal workers' compensation statutes and may recover for injuries resulting from defective design specifications if the injuries arise out of or in the course of his employment. As with all workers' compensation schemes, the statutes provide an assured minimum level of compensation in exchange for relief from the vagaries of litigation. ${ }^{23}$ The Federal Employees Compensation Act ("FECA"), ${ }^{24}$ which covers the government's civilian employees, has an express exclusivity clause ${ }^{25}$ that precludes recovery under the FTCA. Although the statute governing compensation of military personnel ${ }^{26}$ contains no such exclusivity clause, its very existence has been held to bar suits under the FTCA. ${ }^{27}$

Plaintiffs who have no employment relationship with the government may benefit from special legislation-for example, the Military Claims $\mathrm{Act}^{28}$ or the Swine Flu Act ${ }^{28}$ - that creates a nar-

21 Id. at 799.

22 See Peck, Laird v. Nelms: A Call for Review and Revision of the Federal Tort Claims Act, 48 WASH. L. REv. 391 (1973); Reynolds, Strict Liability Under the Federal Tort Claims Act: Does "Wrongful" Cover a Few Sins, No Sins, or Non-Sins?, 23 Am. U.L. Rev. 813 (1974); 6 Akron L. REv. 105 (1973); Case Comment, 25 U. FlA. L. Rev. 408 (1973).

${ }^{2 s}$ See Weisgall, Product Liability in the Workplace: The Effect of Workers' Compensation on the Rights and Liabilities of Third Parties, 1977 WIs. L. REv. 1035, 1039.

245 U.S.C. $\$ \S 8101-8193$ (1976).

${ }^{25}$ Id. § 8116(c).

26 Veterans' Benefits Act, 38 U.S.C. \$§ 101-5228 (1976).

27 See Feres v. United States, 340 U.S. 135, 144-45 (1950), which involved injuries to servicemen "incident" to their military service. In one of the three cases consolidated for Supreme Court review, the soldier had a clear negligence claim: an Army surgeon had left a 30 -inch towel in the soldier's stomach after abdominal surgery. Id. at 137.

The Supreme Court offered three reasons for barring recovery under the FTCA. First, under the FTCA the government is relegated to the status of a private individual, but in the military context there is "no liability of a 'private individual' even remotely analogous to that . . . [asserted] against the United States." Id. at 141. No individual can conscript or mobilize an army as the government can; no individual superior can be liable to a soldier for injuries suffered in the service. Id. at 141-42. Second, the FTCA incorporates state law for its rules of decision, but relations between a soldier and the government should be subject to uniform, federal law. Id. at 142-44. Finally, the existence of compensation schemes for injured servicemen makes reliance on the FTCA unnecessary. Id. at 144-45.

${ }^{28} 10$ U.S.C. $\$ \S 2731-2737$ (1976). This act provides that the United States may settle claims up to $\$ 25,000$ for damage to or loss of real or personal property, personal injury, or 
rowly defined waiver of sovereign immunity. Otherwise, plaintiffs can sue the government for its defective designs only if they can bring themselves within the FTCA. Under that act, a negligence action sometimes may be brought, but a strict liability action is always barred. ${ }^{30}$

\section{B. Plaintiff v. Government Contractor}

1. Negligence. A negligence action against an independent contractor focuses on the standard of care he must use in following someone else's design specifications. The contractor will be relieved of liability "if he follows plans which are not so glaringly or patently insufficient that an ordinary prudent manufacturer would not follow them."31 The "glaring and obvious" rule, which applies both to private and to public contracts, ${ }^{32}$ does not deviate from the usual "ordinary care" standard as much as one might think. The independent contractor typically is not considered a specialist, for his primary responsibility is to follow orders; ${ }^{33}$ where the contractor hires a specialist who is just as capable of assessing the design as is the designer himself, the contractor is held to the ordinary

death, if the injury is "caused by a civilian officer or employee of [a military] department, or the Coast Guard, or a member of the [military] or Coast Guard . . . acting within the scope of his employment, or otherwise incident to noncombat activities of [the military] or the Coast Guard." Id. § 2733(a).

${ }^{29}$ National Swine Flu Immunization Program of 1976, 42 U.S.C. $\S \S 247 \mathrm{~b}(\mathrm{j})-247 \mathrm{~b}(l)$ (1976). This act gives plaintiffs a direct cause of action against the United States under the FTCA in exchange for a forfeiture of the right to sue the vaccine manufacturers, $i d$. $\S 247 \mathrm{~b}(\mathrm{k})$. The plaintiff can rely on any state law liability theory that would have been available against the manufacturer, $i d . \S 247 \mathrm{~b}(\mathrm{k})(2)(\mathrm{A})(\mathrm{i})$; he must, however, follow the procedural and administrative requirements of the FTCA, id. $\S 247 \mathrm{~b}(\mathrm{k})(1)(\mathrm{B})(\mathrm{ii})$.

${ }^{30}$ See text and notes at notes 12-22 supra.

31 Littlehale v. E.I. du Pont de Nemours \& Co., 268 F. Supp. 791,802 n.16 (S.D.N.Y. 1966) (maritime law), aff'd, 380 F.2d 274 (2d Cir. 1967).

${ }^{32}$ For public contracts, see, e.g., Littlehale v. E.I. du Pont de Nemours \& Co., 268 F. Supp. 791 (S.D.N.Y. 1966) (maritime law), aff'd, 380 F.2d 274 (2d Cir. 1967); Person v. Cauldwell-Wingate Co., 187 F.2d 832 (2d Cir.) (New York law), cert. denied, 341 U.S. 936 (1951); Russell v. Arthur Whitcomb, Inc., 100 N.H. 171, 121 A.2d 781 (1956); Ryan v. Feeney \& Sheehan Bldg. Co., 239 N.Y. 43, 145 N.E. 321 (1924). For private contracts, see, e.g., Spangler v. Kranco, Inc., 481 F.2d 373 (4th Cir. 1973) (Virginia law); Davis v. Henderlong Lumber Co., 221 F. Supp. 129 (N.D. Ind. 1963) (Indiana law); Moon v. Winger Boss Co., 205 Neb. 292, 287 N.W.2d 430 (1980).

${ }^{33}$ See Ryan v. Feeney \& Sheehan Bldg. Co., 239 N.Y. 43, 45, 145 N.E. 321, 321 (1924) ("How was an ordinary contractor or builder to know [the strength of iron supports and braces and the proper angles at which they should be placed]? The matter was for the engineers and architects to determine and design." The contractor "was justified in relying upon the experience and skill of the architect and supervising engineer."). 
care standard of the expert. ${ }^{34}$

2. Strict Liability. Depending on the applicable state law, the plaintiff also may state a cause of action against the contractor in strict liability. A contractor can be held liable for defective design specifications supplied by the government in jurisdictions that recognize a cause of action based on defective design ${ }^{35}$ and vicarious liability of those in the chain of distribution. ${ }^{36}$

Most states recognize at least one form of vicarious liability-retailer liability for a defectively designed or manufactured product, even though the defect is latent and therefore not discoverable by investigation. ${ }^{37}$ A plaintiff's cause of action against a contractor for the defective design specifications of another is analogous to a cause of action against a retailer for either the construction or design defects of the product manufacturer. Consequently, those states with retailer liability are likely to recognize a cause of action against a contractor for defective design when the specifications are supplied by someone else.

Section 402A of the Restatement (Second) of Torts ${ }^{38}$ sets out

s4 Person v. Cauldwell-Wingate Co., 187 F.2d 832 (2d Cir.) (New York law), cert. denied, 341 U.S. 936 (1951).

${ }^{35}$ The extension of strict liability principles to cases of design defect has been criticized, see Birnbaum, Unmasking the Test for Design Defect: From Negligence [to Warranty] to Strict Liability to Negligence, 33 Vand. L. Rsv. 593, 599-600 (1980); Hoenig, Product Designs and Strict Tort Liability: Is There a Better Approach?, 8 Sw. U.L. Rev. 109, 123-36 (1976). See generally R. EpsteIN, supra note 5; Henderson, supra note 5. Contra, Twerski, supra note 5.

36 Vicarious liability holds a retailer liable for design defects caused by those further back in the chain of distribution. Its theory is that the plaintiff should be able to sue the party he has dealt with and knows most about, leaving the battles over apportionment of liability to the parties elsewhere in the distributional chain. See, e.g., Vandermark v. Ford Motor Co., 61 Cal. 2d 256, 391 P.2d 168, 37 Cal. Rptr. 896 (1964); text and note at note 46 infra. Parallel reasoning would allow the plaintiff here to sue the government contractor, leaving it to the contractor to seek indemnity from the government designer. See text and notes at notes $46-79$ infra.

37 Restatement (Second) of Torts § 402A, Comment $f$ (1965) [hereinafter cited as RestatemenT]: "The rule stated in this Section applies to any person engaged in the business of selling products for use or consumption. It therefore applies to any manufacturer of such a product, to any wholesale or retail dealer or distributor, and to the operator of a restaurant." See, e.g., O.S. Stapley Co. v. Miller, 103 Ariz. 556, 447 P.2d 248 (1968); Vandermark v. Ford Motor Co., 61 Cal. 2d 256, 391 P.2d 168, 37 Cal. Rptr. 896 (1964); Hiigel v. General Motors Corp., 190 Colo. 57, 544 P.2d 983 (1975); Crowe v. Public Bldg. Comm'n, 74 IIl. 2d 10, 383 N.E.2d 951 (1978); Kleve v. General Motors Corp., 210 N.W.2d 568 (Iowa 1973); Newmark v. Gimbel's, Inc., 54 N.J. 585, 258 A.2d 697 (1969); Mead v. Warner Pruyn Div., 57 A.D.2d 340, 394 N.Y.S.2d 483 (1977); Moss v. Polyco, Inc., 522 P.2d 622 (Okla. 1974); Dippel v. Sciano, 37 Wis. 2d 443, 155 N.W.2d 55 (1967). Contra, Sam Shainberg Co. v. Barlow, 258 So. $2 \mathrm{~d} 242$ (Miss. 1972).

3s That section provides: 
the prerequisites for a products liability suit. Strict liability for personal injury or property damage attaches to the seller of a defective product when it reaches the consumer in the same condition as when sold, even though the seller exercised due care and the consumer had no contractual relationship with him. The requirements would appear to apply to a government contractor who manufactures a product in accordance with the government's design specifications. If the design is defective, the product as manufactured will be defective when it leaves the contractor's control. Assuming that causation is shown and that there is no evidence of misuse or assumption of risk, the contractor fits into the strict liability mold much as the typical product manufacturer does.

One potential hurdle to recovery is the Restatement's requirement that the products liability defendant be a "seller [of the defective and unreasonably dangerous product] . . . engaged in the business of selling such a product."39 Courts that find the contractor liable in the government or private design defect case use a broad definition of "sell," rejecting the contractor's claim that he is an assembler rather than a seller.40 Instead they emphasize that the contractor is paid for each product manufactured, is within the chain of distribution, and intentionally places the product in the stream of commerce. ${ }^{41}$

$\S$ 402A. Special Liability of Seller of Product for Physical Harm to User or Consumer. (1) One who sells any product in a defective condition unreasonably dangerous to the user or consumer or to his property is subject to liability for physical harm thereby caused to the ultimate user or consumer, or to his property, if

(a) the seller is engaged in the business of selling such a product, and

(b) it is expected to and does reach the user or consumer without substantial change in the condition in which it is sold.

(2) The rule stated in subsection (1) applies although

(a) the seller has exercised all possible care in the preparation and sale of his product, and

(b) the user or consumer has not bought the product from or entered into any contractual relation with the seller.

Some jurisdictions have adopted strict liability without reference to the RESTATEMENT.

${ }^{30} I d . \S 402 \mathrm{~A}(1)(\mathrm{a})$.

${ }^{40}$ See, e.g., Foster v. Day \& Zimmermann, Inc., 502 F.2d 867 (8th Cir. 1974) (Iowa law); Delaney v. Towmotor Corp., 339 F.2d 4 (2d Cir. 1964) (New York law); Bachner v. Pearson, 479 P.2d 319 (Alaska 1970).

${ }^{4}$ See, e.g., Foster v. Day \& Zimmermann, Inc., 502 F.2d 867, 872 (8th Cir. 1974) (Iowa law) ("Whether the manufacturer 'sells' his product in the normal sense of that word, leases it, or supplies it for a sole purchaser under contractual arrangements such as those present here, the policy considerations involving the doctrine of strict liability remain the same."). A cost-plus contract by which a product is put into commerce is also an "essentially commercial" transaction, and strict liability therefore attaches. Challoner v. Day \& Zimmermann, Inc., 512 F.2d 77, 82 (5th Cir.) (Texas law), vacated on choice of law grounds, 423 U.S. 3 (1975). 
These courts also reject the argument that even if the defendant is a seller, he sells the service of assembling rather than a product. According to the prevailing view, strict liability is not applicable to suppliers of services. ${ }^{12}$ A repairer or installer may be a seller within the meaning of the Restatement for "injuries caused by defects in products supplied by [him] in the course of [his] services ... [ [but not] for failing to correct or warn of pre-existing defects in products on which [he] has contracted to work." contractor argues that, like the repairer and installer, he performs his services by working with materials and designs provided by others. This analogy is not adequately descriptive of the contractor's role, however. He not only supplies a service, but sells the product as well, and he makes a profit on each product manufactured rather than being paid in sum for his services, as are repairers and installers. Such a "hybrid service-sale transaction"44 distinguishes the government contractor from the installer or repairer. Under a broad interpretation of the "sales" requirement of section 402A, the hybrid service-sale transaction qualifies for strict products liability. ${ }^{40}$

Some argue that a contractor who manufactures a product for the exclusive use of the designer is not exposing the public at large to the risks of a defective product. However, the contractor cannot always anticipate where the product will end up or whether bystanders will be injured. See Littlehale v. E.I. du Pont de Nemours \& Co., 268 F. Supp. 791, 795 (S.D.N.Y. 1966) (13 years after being manufactured for the military, explosives ended up in civilian hands), aff'd, 380 F.2d 274 (2d Cir. 1967). In addition, there is no reason to set lower safety standards because a limited group rather than the public at large is exposed to the product. See Foster v. Day \& Zimmermann, Inc., 520 F.2d 867, 871 (8th Cir. 1974) (Iowa law) ("We believe the public interest in human life and health requires the protection of the law against the manufacture of defective explosives, whether they are to be used by members of the public at large or members of the public serving in our armed forces.").

12 Nickel v. Hyster Co., 97 Misc. 2d 770, 771, 412 N.Y.S.2d 273, 274-75 (Sup. Ct. 1978). See also Laukkanen v. Jewel Tea Co., 78 Ill. App. 2d 153, 162, 222 N.E.2d 584, 589 (1966) (engineer who designed pylons not subject to strict liability); Delta Refining Co. v. Procon, Inc., 552 S.W.2d 387, 389 (Tenn. Ct. App. 1976) (installer not liable in strict liability).

t3 Johnson v. William C. Ellis \& Sons Iron Works, Inc., 604 F.2d 950, 955 (5th Cir. 1979) (Mississippi law). The court noted that, because Mississippi relieves retailers of liability for latent defects, its state courts probably would not impose liability on repairers.

14 Nickel v. Hyster Co., 97 Misc. 2d 770, 773, 412 N.Y.S.2d 273, 276 (Sup. Ct. 1978). See also Newmark v. Gimbel's, Inc., 54 N.J. 585, 593, 258 A.2d 697, 701 (1969); Note, Products and the Professional: Strict Liability in the Sale-Service Hybrid Transaction, 24 Hastings L.J. 111, 116 (1972).

43 See Note, supra note 44, at 131; Sales, The Service-Sales Transaction: A Citadel Under Assault, 10 ST. MARY's L.J. 13, 32 (1978) (Challoner distinguished "from the typical 'service' case since in reality the 'service' provided by the defendant was manufacturing. The entire transaction with the government was commercial in nature."). 
A plaintiff therefore has more promising remedies against the contractor than against the government. He can sue the contractor on a negligence theory if he can show either that the design defect is glaring and obvious or that the contractor has access to expertise that warrants holding him to a more stringent duty of care. He also can sue the contractor in strict products liability in states that first, recognize such a suit for design defects; second, permit vicarious liability; and third, are willing to define the concept of seller under the Restatement to include a contractor.

\section{Government Contractor v. United States}

1. Tort Indemnity. In strict products liability, a defendant who is held responsible for a product defect, such as a retailer, can shift the burden to the party actually responsible for the defect, such as the manufacturer, through a third party indemnity claim. ${ }^{46}$ In United States $v$. Yellow Cab Co., ${ }^{47}$ the Supreme Court held that the United States can be impleaded ${ }^{48}$ on a theory of indemnity or contribution if the government is wholly or partially responsible for an injury. ${ }^{49}$ The Court qualified the Yellow Cab doctrine in Stencel Aero Engineering Corp. v. United States ${ }^{50}$ by holding that a contractor may implead the government only where the original plaintiff could have sued the government directly. ${ }^{51}$ The contractor's suit in that case was barred because the tort victim had surrendered his right to sue under the FTCA for coverage under the

46 See generally Greenstone, Spreading the Loss-Indemnity, Contribution, Comparative Negligence and Subrogation, 13 Forum 266 (1977); Jensvold, A Modern Approach to Loss Allocation Among Tortfeasors in Products Liability Cases, 1974 INs. L.J. 591; O'Donnell, Implied Indemnity in Modern Tort Litigation: The Case for a Public Policy Analysis, 6 Seton Hall L. Rev. 268 (1975); Phillips, Contribution and Indemnity in Products Liability, 42 TenN. L. Rev. 85 (1974); Comment, Contribution and Indemnity: Does the Right Exist Among Joint Tortfeasors When One is Liable on a Theory of Strict Liability?, 18 S. TEx. L.J. 572 (1977); Comment, Comparative Causation, Indemnity, and the Allocation of Losses Between Joint Tortfeasors in Products Liability Cases, 10 ST. Mary's L.J. 587 (1979).

470 U.S. 543 (1951).

48 The impleader action is governed by state law. Id. at 546 .

$49 \mathrm{Id}$. at 552, 556-57. Although Yellow Cab decided only the issue of contribution, the Court in Stencel Aero Eng'r Corp. v. United States, 431 U.S. 666, 669 (1977), interpreted the opinion as deciding the issue of impleader "under a theory of indemnity or contribution."

so 431 U.S. 666 (1977). The Court saw itself as resolving the tension between Feres v. United States, 340 U.S. 135 (1950), which barred recovery, and Yellow Cab, which allowed it. 431 U.S. at 670. For opposing evaluations of the Stencel opinion, see Hertz, The Tort Triangle: Contribution from Defendants Whom Plaintiffs Cannot Sue, 32 MAINE L. Rev. 83 (1980) (supporting Stencel); Note, 29 HAstings L.J. 1217 (1978) (criticizing Stencel).

s1 431 U.S. at $673-74$. 
military compensation system. ${ }^{52}$ The trend of the courts of appeals after Stencel is to deny noncontractual indemnity in situations involving the government's civilian employees as well. ${ }^{53}$ These courts rule against tort indemnity "either because of the language of the exclusive remedy provision [of the FECA] or because of the extinguishment of the government's underlying tort liability to its employees."

United Air Lines, Inc. $v$. Wiener, ${ }^{\mathrm{s}}$ which involved a collision between a commercial airliner and an Air Force jet, illustrates how these limitations work in practice. The injured United passengers recovered from the airline, which in turn sought indemnity from the government. The airline recovered fully for its payments to nongovernmental employees, but was not reimbursed for sums paid to the government's civilian and military employees. ${ }^{56}$

2. Implied Contractual Indemnity. Where tort indemnity is barred, some courts have allowed contractors to shift liability to the government by a claim for implied contractual indemnity if the circumstances of the contractual relationship warrant the inference of a promise by the government to indemnify the contractor. ${ }^{57}$ One court has suggested that contractual indemnification may be implied from the existence of the following factors: first, the product was designed exclusively by the government; second, the design was approved by an agency head; third, the contract required assembly in accordance with government specifications; and finally, the contractor could make no changes without express instructions from the government. ${ }^{58}$ In addition, if the government designer re-

\footnotetext{
${ }^{32}$ The Stencel decision was based on the reasoning in Feres v. United States, 340 U.S. 135 (1950). See note 27 supra.

${ }^{83}$ Galimi v. Jetco, Inc., 514 F.2d 949, 953 (2d Cir. 1975); Travelers Ins. Co. v. United States, 493 F.2d 881 (3d Cir. 1974); Newport Air Park, Inc. v. United States, 419 F.2d 342 (1st Cir. 1969); Murray v. United States, 405 F.2d 1361 (D.C. Cir. 1968); United Air Lines, Inc. v. Wiener, 335 F.2d 379 (9th Cir.), cert. dismissed sub nom. United Air Lines, Inc. v. United States, 379 U.S. 951 (1964). Contra, Wallenius Bremen G. m. b. H. v. United States, 409 F.2d 994 (4th Cir. 1969), cert. denied, 398 U.S. 958 (1970) (indemnity permitted).

${ }^{54}$ Galimi v. Jetco, Inc., 514 F.2d 949, 953 (2d Cir. 1975). See text and notes at notes 2427 supra.

${ }^{68} 335$ F.2d 379 (9th Cir.), cert. dismissed sub nom. United Air Lines, Inc. v. United States, 379 U.S. 951 (1964). Both United Air Lines and the government were sued under the state wrongful death statutes. Id. at 384 .

so Id. at 402-04.

${ }^{57}$ See, e.g., Roy v. Star Chopper Co., 442 F. Supp. 1010 (D.R.I. 1977) (Rhode Island law), aff'd, 584 F.2d 1124 (1st Cir. 1978), cert. denied, 440 U.S. 916 (1979); Travelers Ins. Co. v. United States, 493 F.2d 881 (3d Cir. 1974). See also Comment, Contribution and Indemnity in California, 57 CALIF. L. REv. 490, 493 (1969).
}

s8 Travelers Ins. Co. v. United States, 493 F.2d 881, 888 (3d Cir. 1974). 
jected safety measures proposed by the contractor or undertook to assemble safety devices itself, the contractor might be able to state a claim for implied contractual indemnity on the theory that the government operated as a "co-manufacturer." 59

3. Express Contractual Indemnity. The most effective recourse a contractor has against the government is his contract; he can negotiate for certain express contractual clauses that will clarify the distribution of risk from the outset. There are numerous forms of agreement that can be used by a government contractor, ranging from a fixed-price contract, where the contractor accepts full liability, to a cost-reimbursement contract, where the government bears some or all of the risk. ${ }^{60}$

There is limited statutory authority that allows fixed-price defense contractors to be indemnified under certain circumstances. ${ }^{61}$ In fixed-price contracts for research and development, indemnification for liability from unusually hazardous risks may be provided if the loss or injury to persons or property arises from the direct performance of the contract and if the harm is not compensated by insurance or otherwise. ${ }^{62}$ A second grant of indemnifica-

${ }^{69}$ Cf. Roy v. Star Chopper Co., 442 F. Supp. 1010, 1020 (D.R.I. 1977) (Rhode Island law) (nongovernmental designer), aff'd, 584 F.2d 1124 (1st Cir. 1978), cert. denied, 440 U.S. 916 (1979). The court did not allow the express representation of the purchaser-designer to constitute a defense in the original suit by the plaintiff against the contractor. Once the plaintiff recovered, however, the express representations could be used to support a contractual indemnity claim brought by the contractor against the purchaser-designer. Id. at 1021.

Barr v. Brezina Constr. Co., 464 F.2d 1141 (10th Cir. 1972), cert. denied, 409 U.S. 1125 (1973), involving a government designer, denied the contractual indemnity claim. The court's reasoning was perverse, however: indemnity was denied precisely because the contractor had shown his knowledge of the defect by calling it to the attention of the government and unsucessfully seeking permission to depart from the specifications to remedy it.

6o Incentive contracts, a third form of express agreement, can be classified either as fixed-price incentive or as cost-plus-incentive-fee contracts. For purposes of third party liability, they are like fixed-price and cost-reimbursement contracts, respectively. Ginsburg, Allocation of Risk: Contractor Responsibility for Injury to Government Property and to Third Parties Under Supply and $R$ \& D Contracts, 2 Pub. ConT. L.J. 333, 352 (1969). The only form of contract that cannot be used in military procurement is the cost-plus-a-percentage-of-cost type. 10 U.S.C. $\$ 2306$ (a) (1976); Armed Services Procurement Regulation, 32 C.F.R. § 3-401(a)(2) (1980) [hereinafter cited as ASPR].

B1 10 U.S.C. $\S 2354$ (a) (1976); 50 U.S.C. \$§ 1431-1435 (1976) (commonly known as Public Law 85-804 and hereinafter so cited). This authorization is reflected in a group of contractual provisions, set forth in government regulations, that are to be used "when applicable." See, e.g., ASPR, 32 C.F.R. § 7-303 (1980) (fixed-price contract); id. § 7-303.61 (indemnification under 10 U.S.C. § 2354) (fixed-price contract); id. \$ 7-303.62 (indemnification under Public Law 85-804) (fixed-price contract).

${ }_{62} 10$ U.S.C. § 2354(a) (1976); ASPR, 32 C.F.R. § 7-303.61 (1980) (fixed-price R \& D contract). See also ASPR, 32 C.F.R. § 10-701 (1980) (indemnification under research and 
tion is found in the Executive Order ${ }^{63}$ implementing Public Law

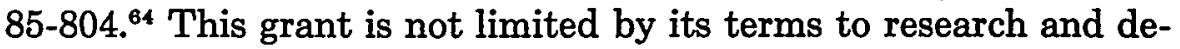
velopment contracts, but permits the Defense Department to enter into an indemnity agreement when the contract involves an unusually hazardous or nuclear risk and when the Secretary or his representative decides the national defense will be facilitated thereby. The Executive Order permits indemnification beyond the contract ceiling price for third party liability; ${ }^{65}$ it also allows the indemnification provision to be applied to the subcontractor. ${ }^{68}$

The cost-reimbursement contract affords the contractor greater protection: third party liability costs generally are included within the rubric of costs the government will reimburse. ${ }^{67}$ One drawback, however, is that a cost-reimbursement contract often contains a "limitation of cost" or "limitation of funds" clause, which obligates the government to reimburse the contractor only up to the level of appropriations for the particular contract. ${ }^{68}$ As payments are made to the contractor, there is less money left in reserve to pay liability costs. ${ }^{68}$ Both the General Services Administration $^{70}$ and the Department of Defense ${ }^{71}$ have promulgated regulations eliminating the ceiling for third party liability claims. Both sets of regulations provide that in cost-reimbursement supply contracts and in research and development contracts, the government

development contracts against unusually hazardous risks).

s3 Exec. Order No. 10,789, 23 Fed. Reg. 8897 (1958), reprinted at 50 U.S.C. § 1431 (1976) (as amended). See also ASPR, 32 C.F.R. § 7-303.62 (1980) (fixed-price); id. § 10-702 (indemnification under Public Law 85-804).

64 50 U.S.C. \$§ 1431-1435 (1976); see note 61 supra.

os Exec. Order No. 10,789, § 1A, 23 Fed. Reg. 8897 (1958), reprinted at 50 U.S.C. § 1431 (1976) (as amended).

${ }^{8}$ Id. § $1 \mathrm{~A}(\mathrm{~b})(1)(\mathrm{D})$. See also Ginsburg, supra note 60, at 359.

oz See, e.g., Federal Procurement Regulation, 41 C.F.R. § 1-7.204-5(c) (1980) [hereinafter cited as FPR] (supply contract); id. § 1-7.404-9(a) (R \& D contract); ASPR, 32 C.F.R. § 7-203.22 (1980) (supply contract); id. § 7-402.26 (R \& D contract). The General Services Administration promulgates the Federal Procurement Regulations, which are binding on all government agencies. Implementation and supplementation are left to individual agencies. The statutory authority for indemnification provisions in cost-reimbursement contracts is found at 10 U.S.C. $\S 2354$ (a) (1976); 50 U.S.C. $\$ \S 1431-1435$ (1976) (Public Law 85-804). See also ASPR, 32 C.F.R. $\S 403.56$ (1980) (indemnification under 10 U.S.C. $\S 2354$ ) (cost-reimbursement contract); id. $\S 403.57$ (indemnification under Public Law 85-804) (cost-reimbursement contract).

${ }^{\text {es }}$ See, e.g., FPR, 41 C.F.R. § 1-7.202-3 (1980) (supply contract); id. § 1-7.402-2 (R \& D contract); ASPR, 32 C.F.R. $\S 7-203.3$ (1980) (supply contract); id. § 7-402.2 (R \& D contract).

68 Ginsburg, supra note 60, at 337.

70 FPR, 41 C.F.R. § 1-7.204-5 (1980) (supply contract); id. § 1-7.404-9 (R \& D contract).

${ }^{71}$ ASPR, 32 C.F.R. § 7-203.22 (1980) (supply contract); id. § 7-402.26 (R \& D contract). 
will pay the reasonable costs of that portion of the contractor's insurance that is "allocable to this contract"; that the government will reimburse the contractor for liabilities to third parties for property damage or personal injury, regardless of the "limitation of funds" clause; and that the government will reimburse the contractor for liability "whether or not caused by [his] negligence," except in cases of "willful misconduct or lack of good faith." tractor covered by these regulations therefore can secure full reimbursement for insurance costs and liabilities in excess of insurance coverage. ${ }^{73}$

4. Special Indemnity Provisions. Legislation providing for contractor indemnification sometimes is enacted to foster particular activities. For instance, the Price-Anderson Act ${ }^{74}$ provides that the United States will indemnify a nuclear facility for nuclear accidents that exceed the required level of insurance protection, if the facility complies with licensing and financial prerequisites. ${ }^{76}$ The statute has two stated purposes: to "protect the public" and to "encourage the development of the atomic energy industry."

If the government must deal with all suppliers as a group, they may have enough leverage to demand a legislative solution to the

${ }^{72}$ FPR, 41 C.F.R. § 1-7.204-5 (1980) (supply contract); id. § 1-7.404-9 (R \& D contract); ASPR, 32 C.F.R. § 7-203.22 (1980) (supply contract); id. § 7-402.26 (R \& D contract). Implementation is described in the "allowable cost, fee, and payment" clause, which provides an exception to the general requirement that the contractor release the government from liability under the contract, once performance is completed, for

[c]laims, together with reasonable expenses incidental thereto, based upon liabilities of the Contractor to third parties arising out of the performance of this contract: Provided, however, That such claims are not known to the Contractor on the date of the execution of the release; and provided further, that the Contractor gives notice of such claims in writing to the Contracting Officer not more than 6 years after the date of the

release or the date of any notice to the Contractor that the Government is prepared to make final payment, whichever is earlier . . . .

FPR, 41 C.F.R. § 1-7.202-4(f)(2)(ii) (1980) (supply contract); id. § 1-7.402-3(a) (R \& D contract). See also ASPR, 32 C.F.R. § 7-203.4(L)(ii)(B) (1980) (supply contract); id. § 7402.3(a) ( $R$ \& $D$ contract).

${ }^{23}$ One procedural problem with both implied and express contractual indemnity is that the jurisdiction of the district courts over contract suits against the government is limited to claims under $\$ 10,000$. Larger contract suits must be brought in the Court of Claims, 28 U.S.C. $\S 1346$ (1976). Thus the plaintiff may sue the contractor in tort in a federal district court, while the contractor's third party contract action against the government must be tried separately in the Court of Claims. Murray v. United States, 405 F.2d 1361, 1366 (D.C. Cir. 1968).

7442 U.S.C. $\$ \S 2011-2296$ (1976).

75 Id. \& 2210(a)-(p).

${ }^{76}$ Id. § 2012(i). 
indemnity problem. The Swine Flu Act ${ }^{77}$ was enacted in response to the unwillingness of drug manufacturers and their insurers to participate in the national immunization program unless they were protected from liability. Yielding to pressure, ${ }^{78}$ Congress made the United States, rather than the drug companies, liable to suit for injury or death caused by the vaccine. ${ }^{79}$

\section{Contractor's Defenses Against the Plaintiff}

In addition to the government contract defense, the contractor may invoke general defenses or seek protection under the penumbra of the government's sovereign immunity.

1. General Defenses. The availability and scope of the defenses of contributory negligence, assumption of risk, or plaintiff's misuse of the product depend on state tort law. Likewise, unless precluded by a federal statute, ${ }^{80}$ state law governs the contractor's ability to set off any collateral benefits, such as workers' compensation payments, against the awarded damages. ${ }^{81}$

2. Sovereign Immunity for the Government Agent. Government contractors on occasion have argued sucessfully that they are agents of the sovereign and that the government's immunity therefore should be extended to bar plaintiffs' suits against them. The agency analysis originated in Yearsley v. W.A. Ross Construction Co., ${ }^{82}$ where the defendant construction company, in the process of building dikes under the direction and supervision of the Secretary of War and the Chief of Engineers, washed away part of Yearsley's land. Rather than pursue a cause of action against the United States under the taking clause of the fifth amendment, ${ }^{83}$ Yearsley

77 National Swine Flu Immunization Program of 1976, Pub. L. No. 94-380, 90 Stat. 1113 (codified at 42 U.S.C. $\$ \S 247 \mathrm{~b}(\mathrm{j})-247 \mathrm{~b}(l)(1976)$ ).

78 " [I]n order to achieve the participation in the program of the agencies, organizations, and individuals who will manufacture, distribute, and administer the swine flu vaccine purchased and used in the swine flu program and to assure the availability of such vaccine in interstate commerce, it is necessary to protect such agencies, organizations, and individuals against liability ...."

42 U.S.C. $\$ 247 \mathrm{~b}(\mathrm{k})(1)(\mathrm{A})(\mathrm{i})$ (1976).

79 Id. § $247 \mathrm{~b}(\mathrm{k})(2)(\mathrm{A})(1976)$.

so For example, the FECA requires that the United States be subrogated to an employee's claim against a third party, 5 U.S.C. $\$ 8131$ (1976).

s1 See generally Epstein, Coordination of Workers' Compensation Benefits With Tort Damage Awards, 13 ForUm 464 (1978); Weisgall, supra note 23, at 1063-64.

82309 U.S. 18 (1940).

${ }^{83}$ U.S. ConST. amend. V ("nor shall private property be taken for public use, without just compensation"). 
sued the company. Treating the contractor as an agent of the government, the Supreme Court held that the agent could be liable only "if he exceeded his authority or [if] it was not validly conferred." erty. $^{85}$ They offer no guidance in distinguishing an independent contractor from an agent; they simply state that, as an agent, the contractor is entitled to sovereign immunity.

In Brady $v$. Roosevelt Steamship Co. ${ }^{86}$ however, the Supreme Court declined to apply agency principles across the board to the contractor situation. The case involved a customs inspector who died from injuries sustained on a vessel owned by the government and operated under contract by the steamship company. The company argued that the widow's statutory suit against the government was her sole remedy ${ }^{87}$ and alternatively, that the terms of the company's indemnification agreement made the government the real party in interest. ${ }^{88}$ The Court rejected both contentions. ${ }^{88}$ The agent's liability was not coextensive with the principal's because "'[a]n instrumentality of government he might be and for the greatest ends, but the agent, because he is agent, does not cease to be answerable for his acts." "9o Moreover, "[t]he withdrawal of the right to sue the agent for his torts would result at times in a substantial dilution of the rights of claimants." guished Yearsley as focusing on the propriety of the delegation of authority:

But here the situation is quite different. The question is not whether the [United States Maritime] Commission had authority to delegate to respondent responsibilities for managing and operating the vessel as its agent. It is whether respondent can escape liability for a negligent exercise of that delegated

84309 U.S. at 21 . The opinion characterized the construction company alternatively as a "contractor" and as an "agent." Id. at 20-21.

${ }^{8 s}$ See, e.g., Myers v. United States, 323 F.2d 580 (9th Cir. 1963); Green v. ICI Am., Inc., 362 F. Supp. 1263 (E.D. Tenn. 1973); Dolphin Gardens, Inc. v. United States, 243 F. Supp. 824 (D. Conn. 1965).

317 U.S. 575 (1943).

s7 Id. at 579-82 (citing Suits in Admiralty Act, 46 U.S.C. $\S 741,742$ (1940)).

88317 U.S. at 582.

89 Id. at 582-84.

so Id. at 580 (quoting Sloan Shipyards Corp. v. Emergency Fleet Corp., 258 U.S. 549, 567 (1922)).

91 317 U.S. at 581. 
power if we assume that by contract it will be exonerated or indemnified for any damages it must pay. ${ }^{92}$

Powell v. United States Cartridge Co ${ }^{93}$ limits Yearsley from another direction, emphasizing that agency status is not automatic for government contractors. The contractors in the cases consolidated in Powell ran munitions plants on a cost-plus-fixed-fee basis for the government. The government supplied the materials and had title to the sites, plants, equipment, raw materials, and finished products; the contractors were responsible for storing and loading materials, manufacturing munitions according to government specifications, supervising employees, and operating the plant. The contractors argued that this arrangement amounted to an agency relationship, exempting them from the Fair Labor Standards Act. ${ }^{94}$ Relying on the explicit terms of the contract, ${ }^{95}$ on the government's insistence on private rather than public production, and on the duties of the plant managers, ${ }^{86}$ the Court rejected the argument and found them to be independent contractors. Other courts have followed Powell's reasoning in rejecting claims by independent contractors that they are agents and therefore entitled to invoke the sovereign immunity of their government principal as a defense. ${ }^{97}$

If contractors were assimilated to the government, plaintiffs would lose all causes of action against contractors that could not be pursued against the government. The negligence case that might have been maintained against the contractor would be precluded under the discretionary function exception of the FTCA, ${ }^{98}$ and all strict products liability claims also would fall because of the principles outlined in Laird $v$. Nelms. ${ }^{90}$ The contractor therefore should not enjoy a blanket sovereign immunity defense.

92 Id. at 583-84.

93 339 U.S. 497 (1950).

1 d. at 504-05.

${ }^{95}$ Id. at 505-06. The Court relied especially on language in the contract stating that, "the Contractor is an independent contractor and in no wise an agent of the Government" (emphasis by the Court).

Id. at 506-07.

97 Foster v. Day \& Zimmermann, Inc., 502 F.2d 867 (8th Cir. 1974) (supply contract); Whitaker v. Harvell-Kilgore Corp., 418 F.2d 1010 (5th Cir. 1969) (supply contract); United States v. Pennsylvania Envt'l Hearing Bd., 431 F. Supp. 747 (M.D. Pa. 1977) (facilities contract), aff'd, 584 F.2d 1273 (3d Cir. 1978).

9s See text and notes at notes 12-19 supra.

See text and notes at notes 20-22 supra. 


\section{The Government Contract Defense in Strict Liability Cases}

The contours of the government contract defense in negligence cases already have been explored: the contractor is relieved of liability if the defect is not glaring and obvious. ${ }^{100}$ Many courts have extended this rationale erroneously to strict liability claims against government contractors. ${ }^{101}$ The parameters of a strict liability suit are different, however; unlike in a negligence case, the emphasis in strict liability is on the condition of the product rather than the behavior of the producer. ${ }^{102}$

Moreover, as shown by the foregoing analysis, the contractor has a much greater range of protections against the consequences of the government's defective design specifications than does the plaintiff. In fact, the plaintiff's only real protection arises from his ability to sue the contractor, because most claims against the government are barred by sovereign immunity. ${ }^{103}$

The contractor is not simply the most reachable source of compensation; he is also the appropriate party on whom to impose strict liability because of the role he can play in increasing deterrence and thereby minimizing the risk of accidents. ${ }^{104}$ Although the government usually is in the best position to minimize the risk of defective design specifications, ${ }^{105}$ sovereign immunity reduces its

100 See text and notes at notes 31-34 supra.

101 See, e.g., Hunt v. Blasius, 55 Ill. App. 3d 14, 18, 370 N.E.2d 617, 620 (1977) (finding the glaring and obvious test "persuasive" even in strict liability), aff'd, 74 Ill. $2 d 203,384$ N.E.2d 368 (1978); Moon v. Winger Boss Co., 205 Neb. 292, 287 N.W.2d 430 (1980) (adopting glaring and obvious test in both negligence and strict liability).

102 See text and notes at notes 38-45 supra.

${ }^{103}$ See part II-A supra.

${ }^{104}$ There are a number of other policy justifications for strict liability. Risk spreading-transferring the loss from the injured party to the manufacturer, who is in a better position to bear the loss by spreading it among his customers-is one such rationale. Enterprise liability-the idea that liability costs should be internalized because the product should pay its own way-is another. It sometimes is argued that strict products liability is necessary to relieve the plaintiff of the difficult burden of proving negligence or resorting to the intricacies of contract law and warranty. In addition, the product by its very presence on the market carries an implied representation of safety. See generally R. EPSTEIN, supra note 5; Birnbaum, supra note 35; Bivins, The Products Liability Crisis: Modest Proposals for Legislative Reform, 11 Akron L. REv. 595 (1978); Owen, Rethinking the Policies of Strict Products Liability, 33 VAND. L. REv. 681 (1980); Prosser, The Assault Upon the Citadel (Strict Liability to the Consumer), 69 YALE L.J. 1099 (1960); Wade, On the Nature of Strict Tort Liability for Products, 44 Miss. L.J. 825 (1973).

${ }^{105}$ In some cases the contractor may be able to discover and to correct the defect, or notify the ultimate user, at less cost than the government. See Calabresi \& Hirschoff, supra note 7 , at 1062-64. 
incentives to calculate the costs of the risks it creates. Through their freedom to reject government contracts, however, contractors can bring pressure on the government to encourage accident avoidance. ${ }^{108} \mathrm{~A}$ variety of mechanisms are available, such as cost-reimbursement contracts, indemnity clauses in fixed-price contracts, and agreements to pay insurance premiums. ${ }^{107}$ Implied contractual relief also may be invoked. ${ }^{108}$ There are notable instances where statutory changes have been enacted to meet the demands of government contractors. ${ }^{109}$ These contractual and statutory accommodations transfer the economic burden of defective design specifications from plaintiffs and contractors to the government. By ultimately bearing the costs of its design defects, the government's incentives to encourage accident avoidance are enhanced.

Such measures could be counterproductive, however, removing incentives for the contractor to add his safety efforts to the government's. ${ }^{110}$ The problem can be dealt with by a less-than-wholesale transfer of burdens, leaving the contractor liable for his own negligence and for any defects in construction. Furthermore, when a contractor is in a better position to detect and remedy the defect than the government is, it may be desirable to impose a duty to warn on the contractor. ${ }^{111}$ These mechanisms, while acknowledging the contractor's right to negotiate around the liability rules, would give the contractor sufficient incentives to minimize the risk of defective products.

There is one category of cases in which the government contract defense should be recognized. The deterrent value of imposing liability on the government contractor comes from his ability to reject the contract; if the contractor cannot refuse the contract, he has no bargaining power and hence no ability to shift the costs of

${ }^{108}$ E.g., Coase, The Problems of Social Cost, 3 J.L. \& Econ. 1, 19 (1960) ("when market transactions are so costly as to make it difficult to change the arrangement of rights established by the law . . . the courts directly influence economic activity"). Because the plaintiff cannot recover directly from the government, the transaction costs involved in the contractual arrangements are unavoidable. See also Landes \& Posner, Joint and Multiple Tortfeasors: An Economic Analysis, 9 J. LEGaL STUd. 517 (1980).

${ }_{107}$ See text and notes at notes 60-72 supra.

${ }_{108}$ See text and notes at notes 57-59 supra.

${ }^{100}$ See text and notes at notes 74-79 supra.

110 See Ginsburg, supra note 60, at 344.

111 See Calabresi \& Hirschoff, supra note 7, at 1062-64. Even if the government was the party best placed to issue a warning, the contractor still could be liable if the absence of the warning made the product unreasonably dangerous and if the contractor had control of the product in its dangerous state. See text and notes at notes 6-8 supra. 
liability to the government. For example, in time of war or national emergency, normal business relations between the contractor and the government are disrupted, and the contractor may be confronted with the possibility of a plant seizure if he refuses to accede to government demands. ${ }^{112}$ Under these conditions, the contractor should be relieved of liability for defective design and allowed to rely on the government contract defense. ${ }^{113}$

This exception should be construed narrowly and restricted to those cases in which the normal assumptions about the contractor's leverage and bargaining power necessarily must be wrong. The defense based on coercion should require more than a situation in which the contractor cannot alter or revise government specifications; ;14 it should require that the contractor have no right to reject the contract. Furthermore, the defense should be available only when the contract is entered into during a time of war or national emergency declared in accordance with statutory authority $^{115}$ and should be limited to areas of production that are related

112 The President often is granted statutory authority to regulate the private sector in time of war or declared national emergency. See Katayama, Emergency Procurement Powers, 2 Pub. Cont. L.J. 236 (1969). The Defense Production Act of 1950, 50 U.S.C.A. app. $\S \S 2061-2169$ (1976 \& Supp. 1981), is one major source of emergency power in the postWorld War II era. It gives the President the power to set priorities in fulfilling government contracts and to allocate facilities and materials as he deems necessary for the national defense. Id. $\$ 2071$ (Supp. 1981) (most recent codified extension, Pub. L. No. 96-294, 94 Stat. $633(1980)$ to September 30, 1981. The statute has been extended regularly since 1952, 50 U.S.C.A. app. $\$ 2166$ (Supp. 1981)).

Other statutes give the President powers, effective in war or when war is imminent, to order production or to take possession of any plant whose owners refuse to produce required products at a reasonable price. 10 U.S.C. \$§ 4501, 9501 (1976). During wartime, the President may require production of ships or war material, appropriate all or any part of factory production for use by the government, and take over any factory for use or operation by the government. 50 U.S.C. § 82(b) (1976).

In 1976, Congress ended all existing states of emergency in the National Emergencies Act, Pub. L. No. 94-412, 90 Stat. 1255 (1976) (codified at 50 U.S.C. $\$ \S 1601-1651$ (1976)). See also S. Rep. No. 94-1168, 94th Cong., 2d Sess., reprinted in [1976] U.S. Code Cong. \& AD. News 2288. Even after that Act, however, the President retains his power to declare a state of emergency under appropriate legislation. 50 U.S.C. $\$ 1621$ (a).

${ }^{113}$ This exceptional situation should be distinguished from the broader defense that claims that a contractor is the government's agent and entitled to the government's immunities, criticized in text and notes at notes 82-99 supra. The Eastern District of New York in In re "Agent Orange" Product Liability Litigation, 506 F. Supp. 762, 792-97 (E.D.N.Y. 1980), failed to recognize this distinction.

114 This diluted standard was accepted in Merritt, Chapman \& Scott Corp. v. Guy F. Atkinson Co., 295 F.2d 14, 16 (9th Cir. 1961) (California law).

${ }^{115}$ See, e.g., Casabianca v. Casabianca, 104 Misc. 2d 348, 428 N.Y.S.2d 400 (Sup. Ct. 1980) (government contractor manufactured kitchen equipment according to Army specifications during World War II; court limited holding to products manufactured during the war). 
to military necessity, in which a contractor reasonably could fear intervention if the government's terms were refused. Nor should a contractor who previously has produced a product under normal circumstances be able to take advantage of the government contract defense when he produces the same product during a military emergency. ${ }^{116}$ For example, use of the priority system ${ }^{117}$ to set aside production of an item for use by the military should not justify the government contract defense if the product has been marketed previously by the contractor. Any reluctance to produce on the part of the contractor in that situation might as well be caused by dissatisfaction with the terms of the government's offer, such as pricing or scheduling, as by concern with the safety of design specifications.

\section{CONCLUSION}

The government contract defense should be recognized only in rare cases to relieve a contractor of liability for defective government design specifications in strict products liability suits. Although the plaintiff often is barred at the outset from suing the government, there are several routes a contractor can take in seeking indemnity from the government. Contractual arrangements are the most effective means, and the contractor is in a better bargaining position with the government than is the injured plaintiff. Through their power to refuse contracts, contractors can pressure the government into accepting liability for its design defects. When the contractor is forced to produce in time of war or declared national emergency, the element of coercion eliminates any deterrent function that contractor liability might serve. Under those exceptional circumstances the government contract defense should defeat the plaintiff's claim. Under more normal conditions, the contractor, rather than the plaintiff, should bear the burden of the government's defective design specifications.

Gail Rubin

116 In particular, a contractor with expertise in a certain product line actually may be a cheaper cost avoider than the government, so there is no purpose in shifting the liability away from him even where he is subject to government coercion.

${ }_{117}$ Defense Production Act of 1950, 50 U.S.C.A. app. § 2071 (1976 \& Supp. 1981). See note 112 supra. 